\title{
Research Paper Crop diversification in Akola district
}

See end of the paper for authors' affiliations

Correspondence to :

\section{N.H. GORE}

Department of

Agricultural Economics,

College of Agriculture,

Phaltan, SATARA (M.S.)

INDIA

Paper History :

Received : 23.07.2015

Revised : 25.07.2015;

Accepted : 17.08.2015
AbSTRACT : The present investigation aims in studying the Crop diversification in Akola district. The present study was based on secondary data collected from different government publications. The data covered a period of 15 years i.e., 1995-96 to 2009-10. In all 6 crops were considered for study. Herfindahl index and entropy index has been used to study the extent of crop diversification. In order to study the economics of crop diversification, land concentration was computed for selected years. Tahsilwise analysis showed that the area under Kharif Jowar has found to be decreased in all the tahsils of Akola district. Area under soybean crop was increased in Balapur and Murtijapur tahsil. The area under Wheat has found to be increased in Akot and Patur tahsils. Cotton still remains as major crop of the district. In Akot, Balapur, Murtijapur and Patur tahsils along with Akola district crop diversification has significantly increased during the study period. The diversification from subsistence crop to more commercial crops were took place in selected tahsils. Cotton and Soybean shows increasing land concentration ratio from year 1995-96 to 2009-10, so soybean is more adventitious crops in Akot, Balapur, Murtijapur and Patur tahsils of Akola district.

KeY Words : Crop diversification, Herfindahl index, Entropy index, Land concentration ratio

How To Cite This PAper : Gore, N.H., Lembhe, J.V. and Kolekar, P.L. (2015). Crop diversification in Akola district. Internat. Res. J. Agric. Eco. \& Stat., 6 (2) : 371-375. 